\section{CITAÇÃO}

Guerra, L. \& Branco, L. M. (2020)

Medicina e arte,

Rev. Ciência Elem., V8(04):061.

doi.org/10.24927/rce2020.061

\section{EDITOR}

José Ferreira Gomes,

Universidade do Porto

\section{EDITOR CONVIDADO}

João Lopes dos Santos

Universidade do Porto

\section{RECEBIDO EM}

21 de novembro de 2020

\section{ACEITE EM}

21 de novembro de 2020

\section{PUBLICADO EM}

15 de dezembro de 2020

\section{COPYRIGHT}

(C) Casa das Ciências 2020

Este artigo é de acesso livre, distribuído sob licença Creative

Commons com a designação

CC-BY-NC-SA 4.0, que permite a utilização e a partilha para fins não comerciais, desde que citado o autor e a fonte original do artigo.

\title{
Medicina e arte
}

in casadasciencias.org/banco-imagens

As imagens são de um belo colorido sobre fundo negro. Projetadas numa tela, dir-se-ia ser uma pintura abstrata. Muito de enaltecer os médicos e cientistas que percebem o belo no que fazem. As duas representações que comentamos obtidas por velocimetria de imagem de partículas é um exemplo. Estas imagens são muito interessantes, ambas muito belas! É como o resultado de um pincel de artista que acabasse de plasmar a ideia de representar redemoinhos, um tornar percetível o movimento numa tela! Na imagem da esquerda, a força (o volume) do sangue que desce da aurícula esquerda para o ventrículo percebe-se naquele encaracolado das imagens duma forma que é diferente do que se observa na imagem da direita que denota o refluxo descido da aorta por insuficiência da válvula aórtica. É um encaracolado muito artístico porque, além da forma, as diferentes tonalidades das cores não só combinam muito bem como ajudam a uma expressão mais real dos fluxos sanguíneos. E depois há aquela teia lindíssima dos azuis nas paredes ventriculares... No abstracionismo artístico todas as ideias, quaisquer que sejam, desde que se projetem em formas e cores, são bem acolhidas! A questão é ser-se capaz!...

\section{Levi Guerra}

Medicina, Universidade do Porto
$\mathrm{Na}$ imagiologia cardíaca, uma nova tecnologia estuda os "vórtices" (redemoinhos) que o sangue forma e acrescenta informação ao Doppler a cor. Possibilita estudar a energia cinética das células sanguíneas e avaliar a repercussão dos desvios da normalidade em dilatações ou em alterações degenerativas ou pró-trombóticas.

$\mathrm{Na}$ lindíssima imagem observamos, em visualização computacional, dois ventrículos esquerdos na diástole. 0 cardiologista olha e vê: no da esquerda, um enchimento ventricular sem restrições; no da direita surge um outro fluxo, de regurgitação da válvula aórtica à esquerda, que vai causar uma diminuição da profundidade do "vórtex" de enchimento normal do coração, distorcê-lo e explicar um sopro que se ausculta nas insuficiências valvulares aórticas graves (rodado de Austin Flint). A imagem poderia estar numa galeria de pintura e possui uma simplicidade e intensidade de cor de suster a respiração. É um instantâneo de uma estrutura em movimento, mas não deixa de mostrar a ondulação do fluxo e as suas interferências e apontar a maravilha que é o funcionamento da bomba que é o coração.

Luísa Moura Branco

Hospital de Santa Marta, CHULC, Lisboa

rce.casadasciencias.org

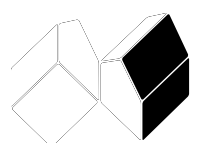




\section{REVISTA DE CIÊNCIA ELEMENTAR}
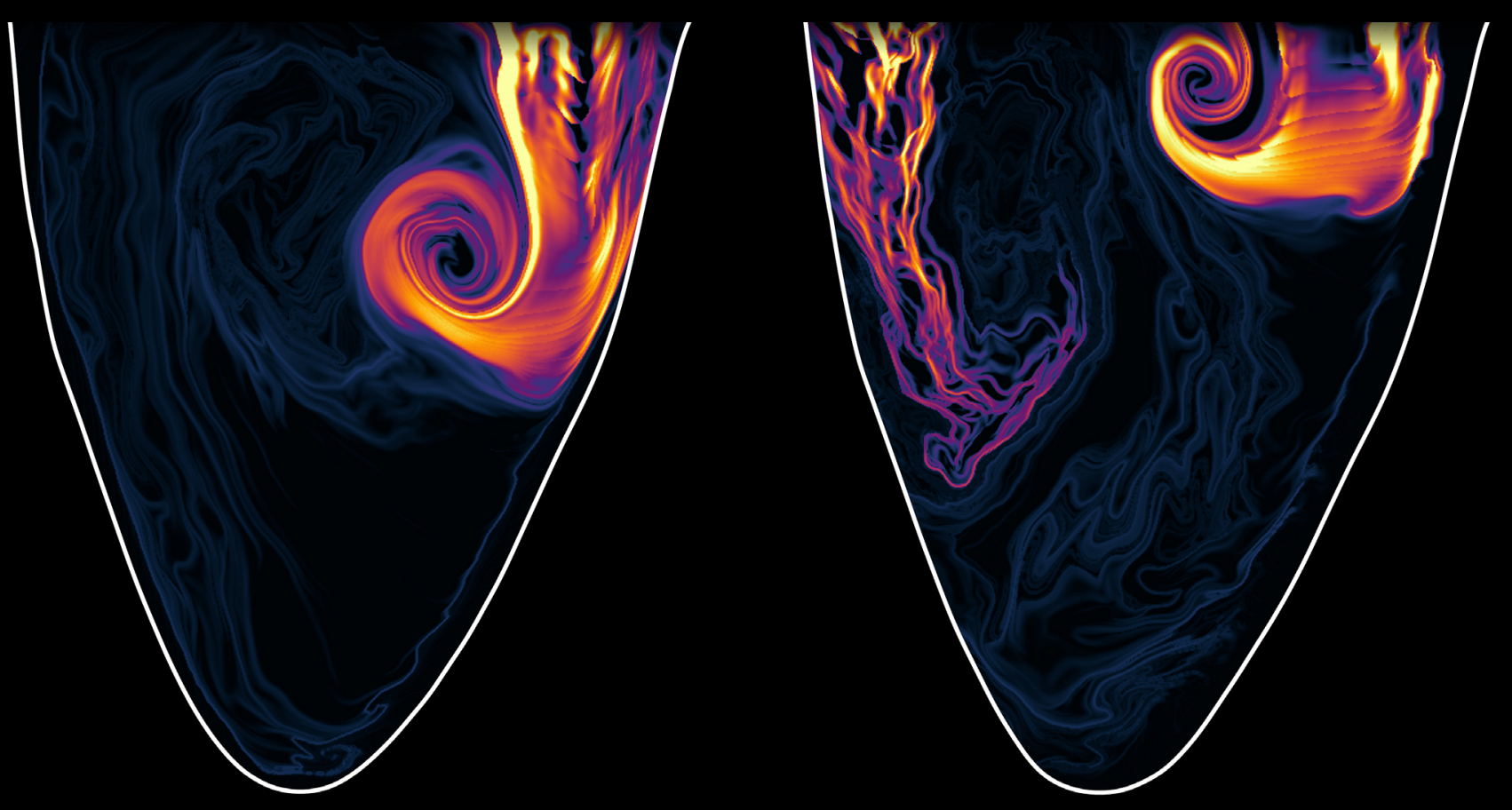